\title{
Measuring the food environment: From theory to planning practice
}

\author{
Leia M. Minaker, ${ }^{a}$ Pat Fisher, ${ }^{b}$ Kim D. Raine, ${ }^{c}$ Lawrence D. Frank ${ }^{d}$
}

Submitted 20 April 2011 / Accepted 19 October 2011 / Published online 21 December 2011

Citation: Minaker, L. M., Fisher, P., Raine, K. D., \& Frank, L. D. (2011). Measuring the food environment: From theory to planning practice. Journal of Agriculture, Food Systems, and Community Development, 2(1), 65- 82. http://dx.doi.org/10.5304/jafscd.2011.021.021

Copyright (C) 2011 by New Leaf Associates, Inc.

\begin{abstract}
The retail food environment is becoming an increasingly important consideration in land use planning decisions. Although many municipal official (or comprehensive) plans call for improved food environments, there are no standard methods by which to assess the implementation of policies reflecting these priorities. Methods developed to
\end{abstract}

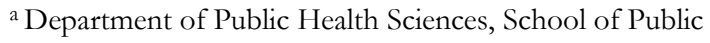
Health, University of Alberta, 3-12 University Terrace, 8303 - 112 Street, Edmonton, AB, T6G 2T4, Canada; lminaker@ualberta.ca

b Region of Waterloo Public Health, 99 Regina Street S, 3rd Floor, Waterloo, ON, N2J 4V3, Canada; pafisher@regionofwaterloo.ca

${ }^{c}$ Corresponding author: Kim D. Raine, Centre for Health Promotion Studies, School of Public Health, University of Alberta, 3-291 Edmonton Clinic Health Academy, 11405-87 Avenue, Edmonton, AB, T6G 1C9, Canada; +1-780-492-9415; kim.raine@ualberta.ca

d School of Community and Regional Planning, University of British Columbia, \#433-6333 Memorial Road, Vancouver, BC, V6T1Z2, Canada; lawrence.frank@ubc.ca assess policy enforcement should be feasible to implement by urban planners and developers, should show some correlation between food environments and residents' health or diet outcomes, and should consider a more nuanced view of food environments than solely focusing on food access. In this paper we review food environment characteristics, theories and conceptual models, and assessment methods with goal of presenting theoretical bases for the selection of food environment assessment tools by public health planners and other practitioners. We examine methods to assess food environments and discuss potential adaptations of the methods to suit the needs of urban planners. A case study of the region of Waterloo is presented to illuminate the potential of food environment assessments for healthy public policy enforcement. Finally we describe implications for public health and urban planning.

\section{Keywords}

built environment, food environment, healthy communities, policy assessment, urban planning 


\section{Introduction}

Evidence regarding the relationship between dietrelated health outcomes and the environments within which people must make their food choices (food environment) continues to build (Black \& Macinko, 2008; Frank, Kerr, Saelens, Sallis, Glanz, \& Chapman, 2009; Sallis \& Glanz, 2009). People who are socioeconomically disadvantaged tend to have decreased access to grocery stores (Block \& Kouba, 2006; Moore \& Diez Roux, 2006; Powell, Slater, Mirtcheva, Bao, \& Chaloupka, 2007; Zenk, Schulz, Hollis-Neely et al., 2005) where healthy foods ${ }^{1}$ tend to be more available and affordable (Block \& Kouba, 2006; Bodor, Rose, Farley, Swalm, \& Scott, 2008; Glanz, Sallis, Saelens, \& Frank, 2007). They also have increased access to fast food outlets, where unhealthy foods tend to be more available (Fleischhacker, Evenson, Rodriguez, \& Ammerman, 2011). However, relationships between people's food environments and diet and/or health status are not fully explained by socioeconomic status (Dubowitz, Heron, Bird et al., 2008). In addition to socioeconomic barriers to food access, other household- or individual-level constraints to accessing healthy food exist, such as geographic barriers, physical limitations due to difficulty lifting groceries, lack of access to a car for food shopping, or perceptions of neighborhood safety (Burns, Bentley, Thornton \& Kavanagh, 2011; Casagrande et al., 2011; Cummins \& MacIntyre, 2006). Neighborhoods that provide residents with access to healthy, affordable foods create a protective context in which healthy diets can be promoted and sustained.

Various researchers, practitioners and community groups are working to improve population diet quality through improvements to food environments (Ohri-Vachaspati \& Leviton, 2010). At least six reviews published in the last five years indicate

\footnotetext{
${ }^{1}$ Numerous definitions of healthy foods exist and can incorporate aspects of the amount of key nutrients or energy sources within foods such as fat, trans fat, salt or sugar (British Columbia Ministry of Education \& British Columbia Ministry of Healthy Living and Sport, 2010), nutrient density (Drewnowski, 2005), preparation options (e.g., frying vs. baking or boiling), and the level of processing (Hamelin, Lamontagne, Ouellet, Pouliot, \& Turgeon O’Brien, 2010).
}

the substantial interest of public health and urban planning researchers and practitioners in studying food access (Black \& Macinko, 2008; Kamphuis, Giskes, de Bruijn, Wendel-Vos, Brug, \& van Lenthe, 2006; McKinnon, Reedy, Morrisette, Lytle, \& Yaroch, 2009; Raine et al., 2008; van der Horst et al., 2007; White, 2007). Retail food environments are becoming increasingly important considerations in land use planning decisions in Canada and other developed countries (Ashe et al., 2007; Diller \& Graff, 2011; Ontario Professional Planners Institute [OPPI], 2011; OPPI, 2009). Local governments have begun conducting research to identify disparities in access to healthy food at the neighborhood level (Larsen \& Gilliland, 2008; McNicoll, 2011; Region of Waterloo Public Health, 2004; Saskatoon Health Region Public Health Observatory, 2010). Meanwhile, academic researchers have created and validated tools to assess food environments based on theoretical and conceptual models of the food environment (McKinnon et al., 2009; Ohri-Vachaspati \& Leviton, 2010) and explored how characteristics of the food environment might be related to diet quality and/or dietrelated health outcomes (Casagrande et al., 2011; Cerin et al., 2011; Fleischhacker et al., 2011; Morland \& Evenson, 2009).

Partnerships between academic researchers and local governments to study local food environments can be mutually beneficial. Specifically, current academic research demonstrating the relationship between characteristics of the food environment and health outcomes using robust, valid, and reliable tools can elucidate intervention opportunities for local governments to improve the food environments in their communities. By working collaboratively, regulatory (i.e., development and zoning) and fiscal (i.e., tax abatement) strategies can be tested as health-based interventions for their effectiveness in increasing access to, and consumption of, healthy food at the neighborhood level. Academic researchers can benefit from these partnerships by being granted the opportunity to collect behavioral and dietary data before and after changes to food environments occur, and to participate in disseminating and distilling research results into policy action. Given that there 
are no standard measures by which to assess the food environment, development of common measures and the desire to translate research into practice are currently high priorities in the field of food environment assessment (Ohri-Vachaspati \& Leviton, 2010).

In this paper we present a review of food environment characteristics, theories and conceptual models, and assessment methods for the purpose of presenting theoretical bases for the selection of food environment assessment tools to public health planners and other practitioners interested in assessing their local food environment. We also describe strategies for improving food environments and current evidence on food environment interventions. A case study is presented to illuminate the potential of food environment assessment for healthy public policy development. The paper concludes with implications for public health and urban planning professionals.

\section{Food Environment Characteristics}

In general, four objectively measured characteristics of food environments have been identified as contributing to diet and/or health outcomes: food access, food availability, food affordability, and food quality (Cummins et al., 2009; OhriVachaspati \& Leviton, 2010).

\section{Food Access}

The concept of food access often reflects a geographical perspective of the food environment and includes measures such as proximity (i.e., distance to the nearest specified type of food outlet) (Apparicio, Cloutier, \& Shearmur, 2007; Larsen \& Gilliland, 2008; Sharkey \& Horel, 2008; Zenk, Schulz, Israel et al., 2005), density (e.g., proportion or ratio of food stores per area, buffer zone, or population; concentration of fast food outlets as measured by locations per roadway mile) (Inagami, Cohen, Brown \& Asch, 2009; Moore \& DiezRoux, 2006; Moore, Diez-Roux, Nettleton \& Jacobs, 2008; Spence, Cutumisu, Edwards, Raine, \& Smoyer-Tomic, 2009) and variety (e.g., number of food stores or food service places within a specified buffer zone) (Andreyeva, Blumenthal, Schwartz, Long \& Brownell, 2008; Apparicio et al.,
2007; Morland \& Evenson, 2009). Literature reviews examining the relationship between food access and diet and/or health outcomes have shown generally positive results, with some finding stronger relationships (Holsten, 2009; Larson, Story, \& Nelson, 2009; Papas et al., 2007; Walker, Keane, \& Burke, 2010) than others (Black \& Macinko, 2008; White, 2007). Food access varies by area-level socioeconomic status, so that the poor have decreased access to grocery stores (Block \& Kouba, 2006; Moore \& Diez Roux, 2006; Powell, Slater, Mirtcheva, Bao, \& Chaloupka, 2007; Zenk, Schulz, Israel, et al., 2005) and increased access to fast-food outlets (Fleischhacker et al., 2011). Interestingly, most Canadian studies differ from the international literature in that they find either no consistent patterning of food stores based on area socioeconomic status, or they find that wealthier areas have poorer food access (Apparicio et al., 2007; Black, Carpiano, Fleming \& Lauster, 2011; Kestens \& Daniel, 2010; SmoyerTomic et al., 2008; Smoyer-Tomic, Spence \& Amrhein, 2006). Categorizing different store types as "healthy" (e.g., grocery stores and fruit and vegetable markets) or "unhealthy" (e.g., fast-food outlets and convenience stores) implicitly assumes that restaurant and store type adequately represent healthy food availability and quality. This assumption is not without merit, since these characteristics have been found to differ by store type (Block \& Kouba, 2006; Bodor et al., 2008). However, the application of the Nutrition Environment Measures Survey (NEMS), a validated instrument, found considerable variation of food quality within specific outlet types for both stores (Glanz et al., 2007) and restaurants (Saelens, Glanz, Sallis, \& Frank, 2007). Despite this, relying solely on food access has limitations, since neighborhood differences in food supply exist even after accounting for store type (Baker, Schootman, Barnidge \& Kelly, 2006; Farley, Rice, Bodor, Cohen, Bluthenthal, \& Rose, 2009; Horowitz, Colson, Hebert \& Lancaster, 2004; Zenk, Schulz, HollisNeely et al., 2005). Moreover, viewing food access as merely a geographical construct ignores the reality that physical limitations, lack of access to a car for food shopping, and individual-level economic disadvantage can all impair food access 
(Burns et al., 2011; Coveney \& O’Dwyer, 2009; Cummins \& MacIntyre, 2006). Further, social constructs such as neighborhood disorder, safety concerns, and residents' concerns about food quality may nonetheless impede residents' use of local food stores (Gittelsohn \& Sharma, 2009; Odoms-Young, Zenk, \& Mason, 2009). In other words, operationalizing food access as a geographically constructed variable (e.g., examining diet-related health outcomes in terms of the number of grocery stores within 0.3 mile $(500 \mathrm{~m})$ of an individual's home or in terms of an individual's proximity to the nearest grocery store) fails to capture the lived experience of individuals because it fails to capture factors that affect food access (e.g., economic disadvantage, mobility impairments, or safety concerns).

\section{Food Availability}

The concept of food access can be considered a proxy for food availability, which is the underlying causal mechanism hypothesized to affect residents' diets (e.g., more fresh fruits and vegetables available in an area might lead to increased purchasing and consumption of fruits and vegetables by area residents, which may positively impact health). Food availability refers to the actual foods available in an area. Specific healthy food items of interest may include fruits and vegetables, whole-grain breads, lower fat milk and meat products, and lowsugar cereals (Glanz et al., 2007). Neighborhood healthy food availability, like healthy food access, has been associated with higher neighborhood income (Franco, Diez Roux, Glass, Caballero, Brancati, 2008; Gordon, Purciel-Hill, Ghai, Kaufman, Graham, \& Van Wye, 2011). Lower healthy food availability was significantly associated with poorer dietary patterns, although this association became insignificant after adjusting for race (Franco et al., 2009). Contrary to its hypothesis, another study found higher healthy food availability associated with higher body weight as an indicator of lower health among urban residents of predominantly white neighbourhoods, and with lower weight status among urban residents of predominantly black and low socioeconomic status (SES) neighborhoods (Casagrande et al., 2011). The authors explain their unexpected findings by noting that individuals living in neighborhoods with low healthy food availability choose to travel outside their neighborhoods for food more often than the same subgroup living in neighborhoods with higher healthy food availability. Measuring food availability overcomes some of the limitations associated with relying solely on food access to define a healthy food environment. Specifically, there is no need to assume store type is an adequate proxy for healthy food availability when availability is directly measured.

\section{Food Affordability}

At a population level, there is an inverse relationship between the energy density of foods (kilocalories per gram) and energy cost (dollars per kilocalorie), resulting in the fact that diets high in refined grains and added fats and sugars are more affordable than the recommended diets based on whole grains, fresh vegetables and fruits, and lean meats and dairy (Drewnowski \& Darmon, 2005a; Drewnowski \& Darmon, 2005b). Food affordability, and specifically food and restaurant prices, has been found to exert generally small effects on body weight outcomes, although these findings also seem to vary by socioeconomic status, with the association between prices and body weight stronger among socioeconomically disadvantaged populations (Beydoun, Powell, Chen, \& Wang, 2011; Powell \& Chaloupka, 2009). Among children, relatively higher food prices of fruits and vegetables have been associated with lower frequency of fruit and vegetable intake (Sturm \& Datar, 2011), lower fiber intake, and higher weight (Beydoun et al., 2011). In addition, relative higher prices of fast food have been associated with better diet quality among young children (Beydoun et al., 2011).

\section{Food Quality}

Finally, food quality is a characteristic of the food environment that has been found to vary by store type, with convenience stores generally selling fresh produce of lower quality than grocery stores (Glanz et al., 2007; White et al., 2004). Food quality is related to food availability in that it is the quality of available food (e.g., fruits and vegetables as well as meats and packaged foods) that influences 
purchasing decisions (Zenk et al., 2011). Withered or bruised fresh fruits and vegetables, rotting meats, and expired canned or packaged foods would be an example of poor food quality. Food quality, like food access and food availability, has also been found to vary by socioeconomic status, with more disadvantaged areas selling foods of lower quality (Sloane et al., 2003; Sooman, MacIntyre, \& Anderson, 1993) or perceived lower quality (Kumar, Quinn, Kriska, \& Thomas, 2011). Perceptions of the quality of fresh produce have been associated with fruit and vegetable consumption (Zenk, Schulz, Hollis-Neely, et al., 2005) and identified as an important factor in food choices (Webber, Sobal, \& Dollahite, 2010).

In summary, food access has been the most commonly studied food environment characteristic, and has most often been geographically operationalized, with certain food outlet types being considered "healthy" (e.g., grocery stores) or "unhealthy (e.g., fast food restaurants and convenience stores). Understanding food access solely from a geographic perspective has been criticized for failing to consider how life circumstances (for example, socioeconomic disadvantage or mobility limitations) affect access to food, and for assuming food availability is invariant across store types. Measures of food availability similarly do not consider personal factors that may limit someone's access to healthy foods, but do go beyond measures of food access by assessing actual foods in the area rather than assuming food availability based on store type. Examining food quality and food affordability comes closer to recognizing the lived experience of acquiring food because these characteristics help to explain why someone might not purchase fresh fruits and vegetables (perhaps because they are of poor quality or too expensive), even if they are available.

\section{Food Environment Theory and Conceptual Models}

Several theoretical models of how the food environment may affect food choices have been developed in the last few years (Black \& Macinko, 2008; Ford \& Dzewaltowski, 2008; Glanz, Sallis, Saelens \& Frank, 2005; Lytle, 2009; White, 2007).
Glanz et al. present an ecological conceptual model of food environments that distinguishes between community and consumer nutrition environments. Community nutrition environments are reflected in measures of food access, while consumer nutrition environments represent characteristics of the food environment important to consumers who have already reached their food store or restaurant destinations, such as food availability, food affordability, food quality, and barriers and facilitators to healthy eating. The authors note that sociodemographic factors mediate and/or moderate the impact of environmental variables on eating patterns.

White (2007) presents a causal model for the relationship between socioeconomic factors and dietary intake, mediated by food retailing. White's model is not as clearly ecologically constructed as the Glanz et al. (2005) model, maintaining a fairly individual-level conception of how food retailing might mediate the relationship between SES and dietary intake. For example, although his model incorporates two mediators that are extrinsic to the individual ("Use of supermarkets or local convenience stores" and "Healthiness of prepared food from fast-food outlets"), they are not identified as extra-individual in the model.

In the ecological model presented by Black and Macinko (2008), access to and quality of food and amenities is recognized as a neighborhood-level characteristic that influences dietary intake, and one that reflects characteristics of both community and consumer nutrition environments. Black \& Macinko suggest that neighborhoods either act as effect modifiers or direct mediators on individual behavior, with neighborhood characteristics supporting or thwarting residents' intentions to eat healthy foods.

Ford and Dzewaltowski (2008) present a model in which socioeconomic status moderates the impact of poor quality food environments on eating behaviors. Specifically, individual SES is viewed as a cross-level confounder on the food environment variables of interest, where individuals who are more socioeconomically disadvantaged have less 
healthy eating behaviors all along the gradient of food environment quality. Ford and Dzewaltowski define a high quality food environment as one in which healthy foods are geographically accessible, available, and affordable, a definition which also reflects measures of both the community and consumer nutrition environment as conceived by Glanz et al. (2005).

Finally, Lytle's (2009) conceptual model broadens Ford and Dzewaltowski's (2008) contribution by considering the proportion of variance in eating behaviors explained by individual factors, environmental factors, and social factors. The model indicates that as individual and social factors become increasingly restricted, the environment explains a higher proportion of variance. Conversely, when individual and social factors are less restricted, environmental factors play a smaller role in explaining variance in dietary behaviors. Lytle contextualizes the importance of her conceptual model by suggesting that food environment research may be especially important in populations for whom individual and social factors are very restricted.

Most of the conceptual models described above are explicitly ecological in their construction, recognizing that characteristics of the food environment are a few of the many influences on diet quality and eating behaviors in a population (Black \& Macinko, 2008; Ford \& Dzewaltowski, 2008; Glanz et al., 2005; Lytle, 2009). All of the conceptual models recognize the importance of socioeconomic status as a mediator or moderator of the relationship between food environment characteristics and dietrelated outcomes. Glanz and colleagues' (2005) model is especially clear in terms of organizing how researchers and practitioners can think about the food environments by distinguishing between community and consumer nutrition environments and then further identifying salient food environment characteristics such as food availability, food affordability, and food quality. This paper also highlights the importance of "distance decay" in explaining travel patterns. This approach accounts for the exponential increase in likelihood that someone will visit a destination as distance decreases. Lytle's (2009) model is also helpful in providing theory about the differential impact of food environments on an individual's diet based on the level of restriction of other individual and social factors. Taken together, these two models (Glanz et al., 2005; Lytle, 2009) provide a comprehensive view of food environments and how they interact with other variables to affect population diet quality.

\section{Food Environment Assessment Methods}

The National Cancer Institute, part of the U.S. National Institutes of Health, provides a compilation of articles and instruments that measure the food environment. ${ }^{2}$ Currently the website contains over 500 articles and instruments that assess food stores, home environments, public facilities, restaurants, schools, and worksites. Ohri-Vachaspati and Leviton (2010) provide an excellent critique of available instruments in terms of ease of use, detail, resources required, and psychometric testing. The authors note that the trade-off between simplicity and low cost on one hand and detail and accuracy on the other hand mean that different potential users (e.g., researchers, practitioners, and community organizations) may opt for different assessment methods. Food environment assessment methods vary widely in terms of data collection, with observational tools including checklists (e.g., Nutrition Environment Measures Survey for Stores and Restaurants (Cerin et al., 2011; Glanz, et al., 2007; Saelens et al., 2007)), shelf-space measures of specific "healthy" vs. "unhealthy" foods (Farley et al., 2009; Rose et al., 2009), and geographic information system (GIS)-based measures such as the Retail Food Environment Index (RFEI), which scores environments based on the ratio of the number of fast-food restaurants and convenience stores to supermarkets and specialty food stores within a given buffer zone (e.g., 0.5 mile or $800 \mathrm{~m}$ ) around an individual's home (California Center for Public Health Advocacy, 2008; Spence et al., 2009). Qualitative measures and measures of residents' perceptions of their food environments have also been described, and have been found to differ from objectively measured aspects of food

${ }^{2}$ See https://riskfactor.cancer.gov/mfe/ 
environments (Giskes et al., 2009; Moore, et al., 2008; Mujahid, Roux, Morenoff, \& Raghunathan, 2007).

The following discussion elaborates on the four objective measures described above. The Nutrition Environment Measures Studies in stores (NEMS-S) and restaurants (NEMS-R), which were derived from the Glanz et al. (2005) conceptual model, assessed constructs associated with food purchasing in grocery stores (i.e., the availability of healthy options, price, and quality) (Glanz et al., 2007) and with food consumption in restaurants (i.e., the availability of more healthy foods, facilitators and barriers to healthy eating, pricing, and promotion of healthy and unhealthy foods) (Saelens et al., 2007). Previous studies using NEMS tools to determine healthy food availability have shown associations with residents' weight as a proxy for health (Cerin et al., 2011).

The shelf-space measure assesses objective geographic food availability by measuring the linear shelf space of specific healthy and unhealthy foods in food stores within a given distance of a person's home and then summing the measurements to provide "cumulative shelf space" of the specific foods (Farley et al., 2009; Rose et al., 2009). The shelfspace measure thus provides a measure of arealevel food availability that can be linked to residents' homes, for example, by assessing the length of shelf space devoted to fruits and vegetables within 0.3 mile $(500 \mathrm{~m})$ of a given address. Cumulative shelf-space availability of certain unhealthy foods, specifically energy-dense snack foods, has been positively associated with weight status (Rose et al., 2009).

Finally, the Retail Food Environment Index (RFEI), a ratio of the number of fast food restaurants and convenience stores to supermarkets and specialty food stores in a given area, assesses relative access to healthy food sources. Therefore, a higher RFEI indicates a more "toxic" food environment (based on the assumption that fast food restaurants and convenience stores contribute to a toxic food environment compared to grocery and specialty stores). The RFEI has been associated with residents' weight status in the U.S. (California Center for Public Health Advocacy, 2008) and in Canada (Spence et al., 2009).

Table 1 provides examples of different food environment assessment tools and notes the amount of expertise and resources needed to use the tools (based on Ohri-Vachaspati and Leviton's (2010) categorizations of low, moderate, and high). Assessment methods included in table 1 were chosen to to indicate the range of resourceintensiveness, with the Retail Food Environment Index (RFEI) being the least resource-intensive to implement and the Nutrition Environment Measures Study (NEMS) tools being the most resource-intensive to implement. In addition, assessment methods included in table 1 were chosen to to indicate the range of theoretical foundations. Specifically, researchers and practitioners who have employed the RFEI assume the importance of geographically defined food access in determining food choices or weight status, while those who employ more specific tools such as the NEMS-S or NEMS-R recognize that aspects of consumer nutrition environments (e.g., food affordability, food availability, barriers and facilitators to healthy eating) may play an important role in food purchasing and consumption behavior. Characterizing food environments as cumulative shelf space of different food items implies a more economic, consumer-driven approach to understanding food environments. Where possible, assessment tools that have previously undergone psychometric testing were included in table 1.

\section{Strategies for Improving the Food Environment}

Research regarding associations between attributes of the food environment and individual-level diet and health outcomes is intended to inform "upstream" policy recommendations to improve the diet quality of the population (Lytle \& Fulkerson, 2002). Policy approaches have been justified based on the idea that even if environmental influences on behavior are relatively weak, their daily influence on large segments of the population may help to facilitate improved diet quality at the population-level (Booth et al., 2001). 
Table 1: Examples of Objective Food Environment Assessment Tools

\begin{tabular}{|c|c|c|c|c|c|}
\hline Instrument & $\begin{array}{l}\text { Food outlet } \\
\text { type assessed }\end{array}$ & $\begin{array}{l}\text { Food environment } \\
\text { characteristic } \\
\text { addressed }\end{array}$ & Methodology & $\begin{array}{l}\text { Psychometric tests } \\
\text { conducted? }\end{array}$ & $\begin{array}{l}\text { Expertise and } \\
\text { resources } \\
\text { needed }\end{array}$ \\
\hline $\begin{array}{l}\text { NEMS-S: } \\
\text { Checklist }\end{array}$ & Stores & $\begin{array}{l}\text { - Availability } \\
\text { - Affordability } \\
\text { - } \text { Quality }\end{array}$ & $\begin{array}{l}\text { Objective audits of food } \\
\text { stores }\end{array}$ & $\begin{array}{l}\text { Showed good inter-rater } \\
\text { and test-retest reliability; } \\
\text { good face and construct } \\
\text { validity }\end{array}$ & Moderate-high \\
\hline $\begin{array}{l}\text { NEMS-R: } \\
\text { Checklist }\end{array}$ & Restaurants & $\begin{array}{l}\text { - Availability } \\
\text { - Affordability }\end{array}$ & $\begin{array}{l}\text { Objective audits of } \\
\text { restaurants }\end{array}$ & $\begin{array}{l}\text { Showed good inter-rater } \\
\text { and test-retest reliability; } \\
\text { good face and construct } \\
\text { validity }\end{array}$ & Moderate-high \\
\hline $\begin{array}{l}\text { Shelf-space } \\
\text { measures }\end{array}$ & Stores & - Availability & $\begin{array}{l}\text { Ratio of sum of shelf } \\
\text { space of healthy items } \\
\text { to sum of shelf space of } \\
\text { junk food }\end{array}$ & $\begin{array}{l}\text { Showed good inter-rater } \\
\text { reliability; good face and } \\
\text { construct validity }\end{array}$ & Moderate \\
\hline $\begin{array}{l}\text { RFEl: Ratio of } \\
\text { store types }\end{array}$ & $\begin{array}{l}\text { Stores and } \\
\text { restaurants }\end{array}$ & - Access & $\begin{array}{l}\text { Geographic analysis of } \\
\text { ratio of number of fast- } \\
\text { food outlets and } \\
\text { convenience stores to } \\
\text { grocery and specialty } \\
\text { stores }\end{array}$ & No & Moderate-high \\
\hline
\end{tabular}

Several strategies to improve the food environment for residents have already been employed, including limiting the number and density of fast food and other restaurants, supporting the creation of farmers' markets, community gardens, and grocery stores through financial incentives and zoning exemptions (Ashe et al., 2007; Diller \& Graff, 2011). The 2009 handbook on designing healthy communities produced by Ontario Ministry of Municipal Affairs and Housing and the Ontario Professional Planners Institute (OPPI) recommends "facilitating access to local healthy foods and improving community food security" (Ministry of Municipal Affairs and OPPI, 2009, p. 7) and describes case studies of projects that have purportedly improved food access. However, the handbook neither defines healthy food access nor provides any guidelines for assessing adequate access to healthy food. More recently, the OPPI released a call to action for planning for food systems in Ontario (OPPI, 2011). Of note, the report recommends that planners, with their knowledge and experience, should be incorporated into research related to food systems.
Relevant to the current discussion is the very small number of food environment intervention studies that have been conducted to date. In part, this is because food environment interventions are complex, costly, and time-intensive. Due to this small number, several unresolved questions exist about what components compose a successful food environment intervention, whom to sample, and outcomes of interest (e.g., should food purchases or diet quality of neighborhood residents be measured?). To date, interventions have been aimed at either the consumer nutrition environment (Gittelsohn, Song, et al., 2010; Gittelsohn, Vijayadeva, et al., 2010; Song, Gittelsohn, Kim, Suratkar, Sharma, \& Anliker, 2009), using measures of consumer purchases, diet behaviors and psychosocial factors related to food purchasing and diet, or the community nutrition environment (Cummins, Findlay, Higgins, Petticrew, Sparks, \& Thomson, 2008; Cummins, Findlay, Petticrew, \& Sparks, 2008; Wrigley, Warm, \& Margetts, 2003; Wrigley, Warm, Margetts, \& Whelan, 2002), using measures of store-switching behavior, diet, and psychological factors. Consumer interventions have shown positive 
impacts on some food behaviors and psychosocial factors, but not others; community interventions have similarly shown modest impacts on some factors, and have further been shown to vary by "store switching" behavior (for example, one study found that those who switched to a new grocery store in a previously underserved area increased their fruit and vegetable consumption more than those who did not switch (Wrigley, et al., 2003)). Consumer interventions have been limited by low exposure rates for respondents (for example, one study implemented the intervention in only nine of 100 local food stores (Gittelsohn, Song, et al., 2010), another in only five food stores (Gittelsohn,

\section{Table 2: Food environment Interventions}

\begin{tabular}{|c|c|c|c|}
\hline Author, Year & $\begin{array}{l}\text { Constructs } \\
\text { addressed }\end{array}$ & $\begin{array}{l}\text { Sample size/type; } \\
\text { follow-up time }\end{array}$ & Intervention \\
\hline $\begin{array}{l}\text { Gittelsohn, Song, } \\
\text { et al., 2010; } \\
\text { Song et al., } 2009\end{array}$ & $\begin{array}{l}\text { Food } \\
\text { availability; } \\
\text { point-of- } \\
\text { purchase } \\
\text { promotions }\end{array}$ & $\begin{array}{l}84 \text { respondents } \\
\text { who lived in } \\
\text { intervention and } \\
\text { comparison } \\
\text { areas ( } 48 \% \\
\text { retention rate); } \\
18 \text { month } \\
\text { follow-up }\end{array}$ & $\begin{array}{l}\text { 10-month intervention was } \\
\text { implemented in } 9 \text { of } 100 \\
\text { local food stores. Interven- } \\
\text { tion included print materials, } \\
\text { working with store owners to } \\
\text { increase or decrease supply } \\
\text { of targeted healthy or } \\
\text { unhealthy foods; shelf labels } \\
\text { identifying targeted foods; } \\
\text { information posters; } \\
\text { incentive cards and } \\
\text { coupons; nutrition education } \\
\text { sessions; food samples; } \\
\text { product giveaways; cooking } \\
\text { demonstrations. }\end{array}$ \\
\hline
\end{tabular}

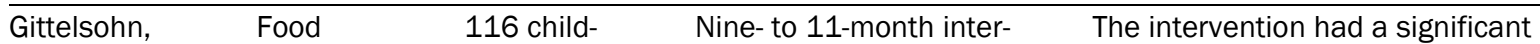

Vijayadeva, et al., availability; caregiver dyads vention in five food stores, impact on caregiver knowledge and 2010 point-of- from two targeting children and purchase intervention and caregivers. Components promotions two comparison included increasing stocks areas; follow-up nutritious foods, point-ofnot specified purchase promotions, interactive sessions.

Main Findings

Intervention group: Healthy food preparation scores increased; purchasing promoted food because of shelf label increased; improvements in other food-related psychosocial factors not statistically significant. perceptions that healthy foods are convenient. Intervention group children s of increased their HEl score for grain servings, total consumption of water, and increased overall HEI score by 9.4\%. Significant impacts were not observed for other caregiver or child psychosocial factors or behaviors.

\begin{tabular}{|c|c|c|c|}
\hline $\begin{array}{l}\text { Cummins, } \\
\text { Findlay, Higgins, } \\
\text { et al., 2008; } \\
\text { Cummins, } \\
\text { Findlay, Petticrew } \\
\text { et al., } 2008\end{array}$ & Food access & $\begin{array}{l}412 \\
\text { respondents at } \\
\text { follow-up from } \\
\text { the intervention } \\
\text { and comparison } \\
\text { areas; } 12- \\
\text { month follow-up }\end{array}$ & $\begin{array}{l}\text { The opening of a large } \\
\text { grocery store in a deprived } \\
\text { area in Scotland. }\end{array}$ \\
\hline
\end{tabular}

There was little evidence for an intervention effect for fruit and vegetable intake or psychological health. People in the intervention group who switched to the new store for grocery shopping were not significantly different than nonswitchers in fruit and vegetable intake, but did significantly improve in measures of psychological health.

\begin{tabular}{llll}
\hline Wrigley, et al., & Food access & 615 & The opening of a large \\
2002; 2003 & & respondents at & grocery store in a deprived \\
& follow-up; 12- & area in England. \\
& month follow-up
\end{tabular}


Vijayadeva, et al., 2010), as well as low response rates. All intervention studies have called for increased "dose" — that is, sustained, comprehensive food environment improvements at multiple levels - for future research. The few published interventions studies and the mixed results found within the studies indicate no clear policy solutions for improving consumer or community food environments. Table 2 describes food environment interventions published to date.

\section{Case Study: The Region of Waterloo}

Waterloo Region is a midsized urban municipality located in southern Ontario, Canada, and is within 200 miles $(320 \mathrm{~km})$ of Toronto, Buffalo, and Detroit. The region includes three urban centers surrounded by four rural townships with a total population of 534,900 (Region of Waterloo Planning, Housing and Community Services, 2009). The region is governed by an upper tier regional council that sets broad directions for the community, as well as seven local city and township councils that provide more local policy solutions. Waterloo Region has historically been progressive in terms of implementing health-promoting policies. For example, the region was one of the first municipalities in Canada to implement policies to go smoke-free in bars and restaurants, as well as one of the first in Ontario to restrict pesticides in residential lawns and gardens.

In June 2009, Regional Council adopted a new Regional Official Plan (ROP) to provide a framework for decision-making on a wide range of planning issues. An official plan is comparable to a "comprehensive plan" in the United States; both documents have essentially the same intent and scope. The main difference between comprehensive plans and official plans is whether municipalities are legally required to prepare them. For example, in Canada, most municipalities are mandated to prepare official plans through provincial legislation, while most state governments do not require comprehensive plans (although municipalities in the United States are able to undertake land use planning). The ROP "contains goals, objectives and policies to manage and direct physical (land use) change and its effects on the cultural, social, economic and natural environment of a municipality" (Region of Waterloo, 2010, para. 2). Among several interesting elements of the ROP is the stated goal of helping to create a healthy food system, which is defined as one in which "all residents have access to, and can afford to buy, safe, nutritious, and culturally-acceptable food that has been produced in an environmentally sustainable way and that sustains our rural communities" (Region of Waterloo Public Health, 2007, p. 4). This goal is unique in its explicit focus on food access and affordability and its implicit focus on quality. Specifically, while many official plans have begun to recognize food access and a healthy food environment, the ROP takes support of these issues one step further by incorporating them into specific land use bylaws (Desjardins, Lubczynski, \& Xuereb, 2011).

One of the policies of the new ROP aims to provide a mix of land uses, including food destinations, within close proximity to each other to facilitate residents' access to locally grown and healthy food products. Although the ROP does not specify how this policy should be implemented, one approach may be to require developers to describe how their proposed development would support citizens' access to safe, nutritious, and affordable foods within the framework of a "complete development application." Municipalities are increasingly requiring developers to submit complete development applications before the review process begins (see, for example, Section 10.D.3 of ROP) in order to avoid delays in approving applications with incomplete information. Presubmission consultation meetings are often held with municipal staff and the developer to ensure that the developer is aware of the municipality's various policy requirements for a proposed development. Specifically, local planners identify the developer's responsibilities for submitting relevant supporting studies, surveys, and information, including studies on transportation impact, environmental impact, and watershed implications. Measuring how the proposed development would support or enhance a healthy food environment is an additional study that could be required of the developer. The current challenge 
is to implement this approach in a way that would make the measurable expectations transparent and clear to all parties involved.

While the goal of establishing healthy food environments in the ROP is certainly laudable, lack of consensus on how to best assess food environments to ensure policy enforcement presents a challenge to planners, developers, and policymakers. Although the region of Waterloo in the past has identified food deserts (areas with reduced or no access to fresh food) within its boundaries (Region of Waterloo Public Health, 2004), a more robust methodology to assess aspects of the consumer nutrition environment (food availability, food affordability, and quality) would benefit municipal staff by providing a more nuanced understanding of food environments that exist in the communities in the region of Waterloo and by demonstrating how different food environment characteristics are associated with residents' health outcomes. Recognizing the trade-off between detail and accuracy on one hand and resourceintensiveness on the other (Ohri-Vachaspati \& Leviton, 2010), region of Waterloo staff also articulated a need to identify the most effective and least resource-intensive way of measuring the food environment for future assessment endeavours, given the competing demands and costs of infrastructure, transportation, and resource-protection activities. Since the measurement of food environments is still at the developmental stage, short forms of instruments shown to adequately portray food environments and maintain statistical variance have not yet been developed (Ohri-Vachaspati \& Leviton, 2010). Hence, a community-university partnership was formed between the Region of Waterloo local government interested in exploring ways to enforce policies related to creating and maintaining healthy food environments, and a group of academics involved in food environment assessment.

A study is currently underway that will attempt to address the food access needs of the Region of Waterloo. NEWPATH (Neighbourhood Environments in Waterloo Region: Patterns of Transportation and Health) is a transdisciplinary research project aiming to evaluate how different urban built environments are associated with a variety of quality of life indicators, including physical activity, diet, food access, air pollution, and greenhouse gas emissions. The project team includes researchers and staff from the University of British Columbia, the University of Alberta, the University of Waterloo, and the Region of Waterloo. One element of this project is focused on assessing associations between food environment characteristics, diet quality, and diet-related health outcomes. This piece of the NEWPATH project employed the four food environment assessment tools described in table 1 in the Region of Waterloo. Collaboration between academic members of the research team and the Region of Waterloo public health planners to determine the most suitable methods for ensuring policy enforcement is ongoing. Specific questions to be answered include, "How accurately does each food environment assessment method predict diet-related health outcomes?"; "What method(s) would be both feasible for public health planners to implement and useful in terms of ensuring 'healthy' food environments are created and maintained as stated in the ROP?"; "Which methodologies would provide the best 'bang for the buck,' considering the multiple priorities of the Region of Waterloo?"; "How can food environment considerations be tied to complete development applications for developers interested in submitting proposals to the Region of Waterloo?".

With respect to the latter question, development review could be augmented to include an evaluation of a proposed land use action's consistency with a neighborhood-level food access plan. This implies that we first need to map out where future food outlets would be located, and to then tie this planning to zoning and development regulations that subsequently would support this type of land use action. Simply requiring space to accommodate food-serving retail does not mean it will happen, however. Therefore, food access planning at the neighborhood level also requires fiscal incentives to promote this type of land use. Evaluating a development proposal's consistency with an adopted land use plan is not new. The city of 
Portland (Oregon) has instituted a "20-minute neighborhood" with a food outlet at the core to acknowledge the fundamental effect of having local access to healthy food choices.

\section{Conclusions}

This paper reviewed food environment characteristics, theories, conceptual models, and assessment methods to provide academics and practitioners with bases for choosing the most appropriate food environment assessment tool. We also described food environment interventions. The case study of the Region of Waterloo has been presented to show how food environment assessments may aid in healthy public policy development and enforcement, and to identify specific questions to create methods for policy monitoring. The communityuniversity partnership provides an opportunity to strengthen local food systems by integrating land use planning documents and academic research. This work can serve the practical needs of municipal staff by grounding a number of constructs of a healthy food system, namely access, availability, affordability, and the quality of healthy foods, in clear, transparent and measurable indicators.

Further, the Region of Waterloo provided a setting for the community-university partnership and insight into what kinds of data are needed to create enforceable policies. This approach may be particularly useful to professional planners and developers in other jurisdictions because it sets clear expectations as to what food-related information is required for the submission of complete development applications. As the partnership continues and data analyses are completed, a clearer picture of whether some food environment constructs or assessment methods are more closely tied to health outcomes than others will emerge, thereby streamlining the amount of information required from developers in completing the applications. The results will enable municipal staff to develop requirements that are evidence-based and to provide clear and consistent expectations for all parties involved in the review process.

As mentioned, Canadian studies to date have differed from much of the international literature in that they find either no consistent patterning of food stores based on area socioeconomic status or they find that wealthier areas have poorer food access (Apparicio et al., 2007; Black et al., 2011; Kestens \& Daniel, 2010; Smoyer-Tomic et al., 2008; Smoyer-Tomic et al., 2006). These studies, however, have relied on measures of food access, and have not examined how consumer nutrition environment characteristics might be patterned by socioeconomic status. The ability of the current study to gain insight into potential socioeconomic patterning of consumer nutrition environment characteristics is a strength and will add to the food environment literature. If consumer nutrition environment characteristics are found to vary by socioeconomic factors, data from the current study could be used by municipal staff to identify priority areas for underserved populations. If the study finds no socioeconomic patterning in the consumer nutrition environment, municipal staff will still benefit from a more thorough understanding of the food environments in their community.

One limitation of attempting to develop tools for the purpose of healthy public policy enforcement is that while municipalities have the authority to approve land use and new development, their ability to control food availability (what kinds of food are sold within food stores and restaurants) and food affordability (how much healthy food costs) is very limited. Often, both healthy and unhealthy foods are available in the same food store or restaurant, and unhealthy foods tend to be cheaper (Drewnowski, 2004; Drewnowski \& Darmon, 2005a; Drewnowski \& Darmon, 2005b). While urban planners have no control over the foods sold or food prices within stores or restaurants, certain types of food outlets have been shown to both have more healthy foods available and at more affordable prices. For example, grocery stores, as opposed to other food stores, tend to offer the greatest variety of high-quality products at the lowest cost (Block \& Kouba, 2006; Bodor et al., 2008; Chung \& Myers, 1999; Glanz et al., 2007). A final limitation of this work is that food environment assessments were only conducted in urban environments and therefore may not be applicable to rural environments. However, given that approximately $80 \%$ of Canadians reside 
in urban areas (Human Resources and Skills Development Canada, 2011), it stands to reason that the tools developed will be applicable to the majority of Canadians. Despite these limitations, going forward to create a checklist for developers with the best evidence currently available in order to support healthy food environments is a commendable objective, and may create more opportunities for residents to maintain a healthy diet than perspectives or practices that vary from planner to planner.

The benefit of employing a variety of methods to assess the strength of associations between aspects of the food environment and residents' diet and health outcomes is that a clearer picture of how and what to measure emerges. By creating a tool that focuses on aspects of the food environment that are related to diet and health outcomes of residents, development proposals can undergo a concise and pointed examination of how the proposal will address the most important of the outcomes of interest.

\section{Acknowledgements}

L.M. Minaker gratefully acknowledges the Canada Graduate Scholarship she receives from the Canadian Institutes of Health Research and a studentship award she receives from the Alberta Heritage Foundation for Medical Research. All authors acknowledge the Heart and Stroke Foundation of Canada (HSFC), the Canadian Institutes of Health Research (CIHR), and the Region of Waterloo, who fund the NEWPATH project. K. D. Raine acknowledges salary support as a HSFC/CIHR Applied Public Health Chair. Further, the authors would like to acknowledge the NEWPATH research team, including Dr. Mary Thompson, Dr. Roy Cameron, Kathleen McSpurren and Andrew Devlin.

\section{References}

Andreyeva, T., Blumenthal, D. M., Schwartz, M. B., Long, M. W., \& Brownell, K. D. (2008). Availability and prices of foods across stores and neighborhoods: The case of New Haven, Connecticut. Health Affairs, 27(5), 1381-1388. http://dx.doi.org/10.1377/hlthaff.27.5.1381
Apparicio, P., Cloutier, M.-S., \& Shearmur, R. (2007). The case of Montreal's missing food deserts: Evaluation of accessibility to food supermarkets. International Journal of Health Geographics. 6(4). http://dx.doi.org/10.1186/1476-072X-6-4

Ashe, M., Feldstein, L. M., Graff, S., Kline, R., Pinkas, D., Zellers, L. (2007). Local venues for change: Legal strategies for healthy environments. Journal of Law, Medicine \& Ethics, 35(1), 138-147. http://dx.doi.org/10.1111/j.1748720X.2007.00118.x

Baker, E. A., Schootman, M., Barnidge, E., \& Kelly, C. (2006). The role of race and poverty in access to foods that enable individuals to adhere to dietary guidelines. Preventing Chronic Disease, 3(3), A76.

Beydoun, M. A., Powell, L. M., Chen, X., \& Wang, Y. (2011). Food prices are associated with dietary quality, fast food consumption, and body mass index among U.S. children and adolescents. The Journal of Nutrition, 141, 304-311. http://dx.doi.org/10.3945/jn.110.132613

Black, J. L., Carpiano, R. M., Fleming, S., \& Lauster, N. (2011). Exploring the distribution of food stores in British Columbia: Associations with neighbourhood sociodemographic factors and urban form. Health \& Place, 17(4), 961-970. http://dx.doi.org/ 10.1016/j.healthplace.2011.04.002

Black, J. L., \& Macinko, J. (2008). Neighborhoods and obesity. Nutrition Reviews, 66(1), 2-20. http://dx.doi.org/10.1111/j.1753-4887. 2007.00001.x

Block, D., \& Kouba, J. (2006). A comparison of the availability and affordability of a market basket in two communities in the Chicago area. Public Health Nutrition, 9, 837-845. http://dx.doi.org/10.1017/PHN2005924

Bodor, J. N., Rose, D., Farley, T. A., Swalm, C., \& Scott, S. K. (2008). Neighbourhood fruit and vegetable availability and consumption: The role of small food stores in an urban environment. Public Health Nutrition, 11(4), 413-420. http://dx.doi.org/10.1017/S1368980007000493

Booth, S. L., Mayer, J., Sallis, J. F., Ritenbaugh, C., Hill, J. O., Birch, L. L.,...Hays, N. P. (2001). Environmental and societal factors affect food choice and physical activity: Rationale, influences, and leverage points. Nutrition Reviews, 59(3), S21S39. http://dx.doi.org/10.1111/j.17534887.2001.tb06983.x 
British Columbia Ministry of Education, and British Columbia Ministry of Healthy Living and Sport. (2010). Guidelines for food and beverage sales in BC schools. British Columbia: Author.

Burns, C., Bentley, R., Thornton, L., \& Kavanagh, A. (2011). Reduced food access due to a lack of money, inability to life and lack of access to a car for food shopping: A multilevel study in Melbourne, Victoria. Public Health Nutrition, 14(6), 1017-1023.

http://dx.doi.org/10.1017/S136898001000385X

California Center for Public Health Advocacy. (2008). Designed for disease: The link between local food environments and obesity and diabetes. UCLA Center for Health Policy Research. Davis, California: Author.

Casagrande, S. S., Franco, M., Gittelsohn, J., Zonderman, A. B., Evans, M. K., Kuczmarski, M. F., \& Gary-Webb, T. L. (2011). Healthy food availability and the association with BMI in Baltimore, Maryland. Public Health Nutrition, 14(6), 1001-1007.

http://dx.doi.org/10.1017/S1368980010003812

Cerin, E., Frank, L. D., Sallis, J. F., Saelens, B. E., Conway, T. L., Chapman, J. E., \& Glanz, K. (2011). From neighborhood design and food options to residents' weight status. Appetite, 56, 693-703. http://dx.doi.org/10.1016/j.appet.2011.02.006

Chung, C., \& Myers, J. (1999). Do the poor pay more for food? An analysis of grocery store availability and food price disparities. Journal of Consumer Affairs, 33, 276-296. http://dx.doi.org/10.1111/j.1745$\underline{6606.1999 . t b 00071 . x}$

Coveney, J., \& O’Dwyer, L. A. (2009). Effects of mobility and location on food access. Health \& Place, 15, 45-55. http://dx.doi.org/10.1016/ j.healthplace.2008.01.010

Cummins, S., Findlay, A., Higgins, C., Petticrew, M., Sparks, L., \& Thomson, H. (2008). Reducing inequalities in health and diet: Findings from a study on the impact of a food retail development. Environment and Planning A, 40(2), 402-422. http://dx.doi.org/10.1068/a38371

Cummins, S., Findlay, A., Petticrew, M., \& Sparks, L. (2008). Retail-led regeneration and store-switching behaviour. Journal of Retailing and Consumer Services, 15(4), 288-295.

http://dx.doi.org/10.1016/j.jretconser.2007.06.002

Cummins, S., \& Macintyre, S. (2006). Food environments and obesity - neighbourhood or nation? International Journal of Epidemiology, 35, 100104. http://dx.doi.org/10.1093/ije/dyi276

Cummins, S., Smith, D. M., Taylor, M., Dawson, J., Marshall, D., Sparks, L., \& Anderson, A. S. (2009). Variations in fresh fruit and vegetable quality by store type, urban-rural setting and neighbourhood deprivation in Scotland. Public Health Nutrition, 12(11), 2044-2050. http://dx.doi.org/10.1017/S1368980009004984

Desjardins, E., Lubczynski, J., \& Xuereb, M. (2011). Incorporating policies for a healthy food system into land-use planning: The case of Waterloo Region, Canada. Journal of Agriculture, Food Systems \& Community Development, 2(1), 1-13.

http://dx.doi.org/10.5304/jafscd.2011.021.003

Diller, P. A., \& Graff, S. (2011). Regulating food retail for obesity prevention: How far can cities go? Journal of Law, Medicine \& Ethics, 39(S1), 89-93. http://dx.doi.org/10.1111/j.1748720X.2011.00575.x

Drewnowski, A. (2004). Obesity and the food environment: Dietary energy density and diet costs. American Journal of Preventive Medicine, 27(S3), S154162. http://dx.doi.org/10.1016/j.amepre.2004.06.011

Drewnowski, A. (2005). Concept of a nutritious food: Toward a nutrient density score. The American Journal of Clinical Nutrition, 82(4), 721-732.

Drewnowski, A., \& Darmon, N. (2005a). The economics of obesity: Dietary energy density and energy cost. American Journal of Clinical Nutrition, 82(S1), S265-S273.

Drewnowski, A., \& Darmon, N. (2005b). Food choices and diet costs: An economic analysis. Journal of Nutrition, 135(4), 900-904.

Dubowitz, T., Heron, M., Bird, C. E., Lurie, N., Finch, B. K., Basurto-Dávila, R., Hale, L., \& Escarce, J. J. (2008). Neighborhood socioeconomic status and fruit and vegetable intake among whites, blacks, and Mexican Americans in the United States. American Journal of Clinical Nutrition, 87, 1883-1891

Farley, T. A., Rice, J., Bodor, J. N., Cohen, D. A., Bluthenthal, R. N., \& Rose, D. (2009). Measuring the food environment: Shelf space of fruits, vegetables, and snack foods in stores. Journal of Urban Health, 86(5), 672-682. http://dx.doi.org/10.1007/s11524-009-9390-3 
Fleischhacker, S. E., Evenson, K. R., Rodriguez, A., \& Ammerman, A. S. (2011). A systematic review of fast food access studies. Obesity Reviews, 12, e460e471. http://dx.doi.org/10.1111/j.1467789X.2010.00715.x

Ford, P. B., \& Dzewaltowski, D. A. (2008). Disparities in obesity prevalence due to variation in the retail food environment: Three testable hypotheses.

Nutrition Reviews, 66(4), 216-228.

http://dx.doi.org/10.1111/j.17534887.2008.00026.x

Franco, M., Diez Roux, A. V., Glass, T. A., Caballero, B., \& Brancati, F. (2008). Neighborhood characteristics and availability of healthy foods in Baltimore. American Journal of Preventive Medicine, 35(6), 561-567. http://dx.doi.org/10.1016/i.amepre.2008.07.003

Franco, M., Diez-Roux, A. V., Nettleton, J. A., Lazo, M., Brancati, F., Caballero, B., Glass, T., \& Moore, L. V. (2009). Availability of healthy foods and dietary patterns: The Multi-Ethnic Study of Atherosclerosis. American Journal of Clinical Nutrition, 89, 897-904. http://dx.doi.org/10.3945/ajen.2008.26434

Frank, L., Kerr, J., Saelens, B., Sallis, J., Glanz, K., \& Chapman, J. (2009). Food outlet visits, physical activity and body weight. Variations by gender and race-ethnicity. British Journal of Sports Medicine, 43, 124-131. http://dx.doi.org/10.1136/bjsm.2008.055533

Giskes, K., van Lenthe, F., Kamphuis, C. B. M., Huisman, M., Brug, J., \& Mackenbach, J. P. (2009). Household and food shopping environments: Do they play a role in socioeconomic inequalities in fruit and vegetable consumption? A multilevel study among Dutch adults. Journal of Epidemiology and Community Health, 63, 113-120. http://dx.doi.org/10.1136/jech.2008.078352

Gittelsohn, J. \& Sharma, S. (2009). Physical, consumer, and social aspects of measuring the food environment among diverse low-income populations. American Journal of Preventive Medicine, 36(4 Suppl.), S161-S165. http://dx.doi.org/10.1016/j.amepre.2009.01.007

Gittelsohn, J., Song, H. J., Suratkar, S., Kumar, M. B., Henry, E. G., Sharma, S., ...Anliker, J. (2010). An urban food store intervention positively affects food-related psychosocial variables and food behaviors. Health Education \& Behavior, 37(3), 390-
402. http://dx.doi.org/10.1177/1090198109343886

Gittelsohn, J., Vijayadeva, V., Davison, N., Ramirez, V., Cheung, L. W. K., Murphy, S., \& Novotny, R. (2010). A food store intervention trial improves caregiver psychosocial factors and children's dietary intake in Hawaii. Obesity, 18(S1), S84-S90. http://dx.doi.org/10.1038/oby.2009.436

Glanz, K., Sallis, J. F., Saelens, B. E., \& Frank, L. D. (2005). Healthy nutrition environments: Concepts and measures. American Journal of Health Promotion, 19(5), 330-333. http://dx.doi.org/10.4278/0890$\underline{1171-19.5 .330}$

Glanz, K., Sallis, J. F., Saelens, B. E., \& Frank, L. D. (2007). Nutrition environment measures survey in stores (NEMS-S) - Development and evaluation. American Journal of Preventive Medicine, 32(4), 282-289. http://dx.doi.org/10.1016/j.amepre.2006.12.019

Gordon, C., Purciel-Hill, M., Ghai, N. R., Kaufman, L., Graham, R., \& Van Wye, G. (2011). Measuring food deserts in New York City's low-income neighborhoods. Health \& Place, 17(2), 696-700. http://dx.doi.org/10.1016/j.healthplace.2010. $\underline{12.012}$

Hamelin, A. M., Lamontagne, C., Ouellet, D., Pouliot, N., \& Turgeon O’Brien, H. (2010). Healthful eating: Beyond food, a global concept. Canadian Journal of Dietetic Practice and Research, 71(2), e21-e27. http://dcjournal.metapress.com/content/x1240313 66k74kp7/?p=19755a0eab214a189c1903ce0e865b6 $\underline{8 \& \mathrm{pi}=0}$

Holsten, J. E. (2009). Obesity and the community food environment: A systematic review. Public Health Nutrition, 12, 1-9

Horowitz, C. R., Colson, K. A., Hebert, P. L., \& Lancaster, K. (2004). Barriers to buying healthy foods for people with diabetes: Evidence of environmental disparities. American Journal of Public Health, 94(9), 1549-1554. http://dx.doi.org/10.2105/AJPH.94.9.1549

Human Resources and Skills Development Canada. (2011). Canadians in context - geographic distribution. Retrieved from http://www4.hrsdc.gc.ca/.3ndic.1t.4r@-eng.jsp?iid $=34$

Inagami, S., Cohen, D. A., Brown, A. F., \& Asch, S. M. (2009). Body mass index, neighborhood fast food and restaurant concentration, and car ownership. Journal of Urban Health. 86(5), 683-695. http://dx.doi.org/10.1007/s11524-009-9379-y 
Kamphuis, C. B. M., Giskes, K., de Bruijn, G. J., Wendel-Vos, W., Brug, J., \& van Lenthe, F. J. (2006). Environmental determinants of fruit and vegetable consumption among adults: A systematic review. British Journal of Nutrition, 96(4), 620-635.

Kestens, Y., \& Daniel, M. (2010). Social inequalities in food exposure around schools in an urban area. American Journal of Preventive Medicine, 39(1), 33-40. http://dx.doi.org/10.1016/j.amepre.2010.03.014

Kumar, S., Quinn, S. C., Kriska, A. M., \& Thomas, S. B. (2011). "Food is directed to the area": African Americans' perceptions of the neighbourhood nutrition environment in Pittsburgh. Health \& Place, 17(1), 370-378. http://dx.doi.org/10.1016/ j.healthplace.2010.11.017

Larsen, K., \& Gilliland, J. (2008). Mapping the evolution of "food deserts" in a Canadian city: Supermarket accessibility in London, Ontario, 1961-2005. International Journal of Health Geographics, 7(1). http://dx.doi.org/10.1186/1476-072X-7-16

Larson, N., Story, M., \& Nelson, M. (2009). Neighborhood environments, disparities in access to healthy foods in the US. American Journal of Preventive Medicine, 36, 74-81. http://dx.doi.org/10.1016/j.amepre.2008.09.025

Lytle, L. A. (2009). Measuring the food environment: State of the science. American Journal of Preventive Medicine, 36(4S), S134-S144. http://dx.doi.org/10.1016/j.amepre.2009.01.018

Lytle, L. A., \& Fulkerson, J. A. (2002). Assessing the dietary environment: Examples from school-based nutrition interventions. Public Health Nutrition, 5(6A), 893-899. http://dx.doi.org/10.1079/PHN2002384

McKinnon, R. A., Reedy, J., Morrisette, M. A., Lytle, L. A., \& Yaroch, A. L. (2009). Measures of the food environment: A compilation of the literature, 19902007. American Journal of Preventive Medicine, 36(4S), S124-S133. http://dx.doi.org/10.1016/j.amepre.2009.01.012

McNicoll, S. (2011). Toronto's food deserts. Retrieved June 27, 2011, from http://sustainontario.com/ 2011/02/08/4050/blog/good-food-ideas-forkids/torontos-food-deserts

Ministry of Municipal Affairs and Housing, and the Ontario Professional Planners Institute (OPPI). (2009, Fall). Planning by design: A bealthy communities handbook. Retrieved from
http://www.ontarioplanners.on.ca/pdf/Healthy_C ommunities Handbook.pdf

Moore, L. V. \& Diez Roux, A. V. (2006). Associations of neighborhood characteristics with the location and type of food stores. American Journal of Public Health, 96, 325-331. http://dx.doi.org/10.2105/AJPH.2004.058040

Moore, L. V., Diez Roux, A. V., Nettleton, J. A., \& Jacobs, D. R. (2008). Associations of the local food environment with diet quality: A comparison of assessments based on surveys and geographic information systems. American Journal of Epidemiology, 167(8), 917-924. http://dx.doi.org/10.1093/aje/kwm394

Morland, K. B., \& Evenson, K. R. (2009). Obesity prevalence and the local food environment. Health \& Place, 15, 491-495. http://dx.doi.org/10.1016/ j.healthplace.2008.09.004

Mujahid, M. S., Roux, A. V. D., Morenoff, J. D., \& Raghunathan, T. (2007). Assessing the measurement properties of neighborhood scales: From psychometrics to ecometrics. American Journal of Epidemiology, 165(8), 858-867. http://dx.doi.org/10.1093/aje/kwm040

Odoms-Young, A. M., Zenk, S., \& Mason, M. (2009). Measuring food availability and access in AfricanAmerican communities: Implications for intervention and policy. American Journal of Preventive Medicine, 36(4 Suppl.), S145-S150. http://dx.doi.org/10.1016/j.amepre.2009.01.001

Ohri-Vachaspati, P., \& Leviton, L. C. (2010). Measuring food environments: A guide to available instruments. American Journal of Health Promotion, 24(6), 410-426. http://dx.doi.org/10.4278/ajhp.080909-LIT-190

Ontario Professional Planners Institute (OPPI). (2011). Planning for food systems in Ontario: A call to action. Retrieved from http://www.ontarioplanners.on.ca/pdf/a call to a ction from oppi june 24 2011.pdf

Papas, M. A., Alberg, A. J., Ewing, R., Helzlsouer, K. J., Gary, T. L., \& Klassen, A. C. (2007). The built environment and obesity. Epidemiological Reviews, 29, 129-143. http://dx.doi.org/10.1093/epirev/mxm009 
Powell, L. M., \& Chaloupka, F. J. (2009). Food prices and obesity: evidence and policy implications for taxes and subsidies. The Millbank Quarterly, 87(1), 229-257. http://dx.doi.org/10.1111/j.14680009.2009.00554.x

Powell, L. M., Slater, S., Mirtcheva, D., Bao, Y., \& Chaloupka, F. J. (2007) Food store availability and neighborhood characteristics in the United States. Preventive Medicine, 44(3), 189-195. http://dx.doi.org/10.1016/j.ypmed.2006.08.008

Raine, K., Spence, J. C., Church, J., Boulé, N., Slater, L., Marko, J.,...Hemphill, E. (2008). State of the evidence review on urban health and healthy weights. Canadian Institute for Health Information (CIHI), Ottawa: Publisher.

Region of Waterloo. (2010). New ROP - Home. Retrieved from http://www.region.waterloo. on.ca/web/region.nsf/97dfc347666efede85256e59 0071a3d4/4a94f7b34be852628525746400708c7c!O penDocument

Region of Waterloo Planning, Housing and Community Services. (2009). Planning Information Bulletin: Population and employment forecasts 2006-2029. Retrieved from http://www.region.waterloo.on.ca/ web/region.nsf/DocID/A28889704733342285257 3700060C1D7/\$file/Population and Employment Forecasts.pdf?openelement

Region of Waterloo Public Health. (2007). A healthy community food system plan. Retrieved June 27 , 2011, from http://chd.region.waterloo.on.ca/web/ health.nsf/8f9c046037662cd985256af000711418/ 54ED787F44ACA44C852571410056AEB0/\$file/ FoodSystem Plan.pdf?openelement

Region of Waterloo Public Health. (2004). Building healthy and supportive communities: A glance at access to food. Retrieved June 27, 2011, from http://chd.region.waterloo.on.ca/en/research ResourcesPublications/resources/FoodAccess.pdf

Rose, D., Hutchinson, P. L., Bodor, J. N., Swalm, C. M., Farley, T. A., Cohen, D. A., \& Rice, J. C. (2009). Neighborhood food environments and body mass index: The importance of in-store contents. American Journal of Preventive Medicine, 37(3), 214-219. http://dx.doi.org/10.1016/j.amepre.2009.04.024

Saelens, B. E., Glanz, K., Sallis, J. F., \& Frank L. D. (2007). Nutrition environment measures study in restaurants (NEMS-R) - Development and evaluation. American Journal of Preventive Medicine, 32(4), 273-281.

http://dx.doi.org/10.1016/j.amepre.2006.12.022

Sallis, J. F., \& Glanz, K. (2009). Physical activity and food environments. Solutions to the obesity epidemic. The Milbank Quarterly, 87, 123-154. http://dx.doi.org/10.1111/j.1468-0009.2009. 00550.x

Saskatoon Health Region Public Health Observatory. (2010). Food access in Saskatoon. Retrieved June 27, 2011, from http://www.saskatoonhealthregion. ca/your health/documents/PHO/Community FoodAccessReport TwoPgSummary.pdf

Sharkey, J. R., \& Horel, S. (2008). Neighborhood socioeconomic deprivation and minority composition are associated with better potential spatial access to the ground-truthed food environment in a large rural area. Journal of $N$ utrition. 138(3), 620-627.

Sloane, D. C., Diamant, A. L., Lewis, L. B., Yancey, A. K., Flynn, G., Nascimento, L. M. et al. (2003). Improving the nutritional resource environment for healthy living through community-based participatory research, Journal of General Internal Medicine, 18, 568-575. http://dx.doi.org/10.1046/ j.1525-1497.2003.21022.x

Smoyer-Tomic, K. E., Spence, J. C., \& Amrhein, C. (2006). Food deserts in the prairies? Supermarket accessibility and neighbourhood need in Edmonton, Canada. Professional Geographer, 58, 307326. http://dx.doi.org/10.1111/j.1467$\underline{9272.2006 .00570 . x}$

Smoyer-Tomic, K. E., Spence, J. C., Raine, K. D., Amrhein, C., Cameron, N., Yasenovskiy, V.,...Healy, J. (2008). The association between neighborhood socioeconomic status and exposure to supermarkets and fast food outlets, Health \& Place, 14(4), 740-754. http://dx.doi.org/10.1016/ j.healthplace.2007.12.001

Song, H. J., Gittelsohn, J., Kim, M., Suratkar, S., Sharma, S., \& Anliker, J. (2009). A corner store intervention in a low-income urban community is associated with increased availability and sales of some healthy foods. Public Health Nutrition, 12(11), 2060-2067. http://dx.doi.org/10.1017/S1368980009005242 
Sooman, A., MacIntyre, S., \& Anderson, A. (1993). Scotland's Health—a more difficult challenge for some? The price and availability of healthy foods in socially contrasting localities in the West of Scotland. Health Bulletin, 51, 276-284.

Spence, J. C., Cutumisu, N., Edwards, J., Raine, K. D., \& Smoyer-Tomic, K. (2009). Relation between local food environments and obesity among adults. $B M C$ Public Health, 9, 192. http://dx.doi.org/10.1186/1471-2458-9-192

Sturm, R., \& Datar, A. (2011). Regional price differences and food consumption frequency among elementary school children. Public Health, 125(3), 136-141. http://dx.doi.org/10.1016/i.puhe.2010.11.016

van der Horst, K., Oenema, A., Ferreira, I., WendelVos, W., Giskes, K., van Lenthe, F., \& Brug, J. (2007). A systematic review of environmental correlates of obesity-related dietary behaviors in youth. Health Education Research, 22(2), 203-226. http://dx.doi.org/10.1093/her/cyl069

Walker, R. E., Keane, C. R., \& Burke, J. G. (2010). Disparities and access to healthy food in the United States: A review of food deserts literature. Health \& Place, 16(5), 876-884. http://dx.doi.org/10.1016/ j.healthplace.2010.04.013

Webber, C. B., Sobal, J., \& Dollahite, J. S. (2010). Shopping for fruits and vegetables. Food and retail qualities of importance to low-income households at the grocery store. Appetite, 54, 297-303. http://dx.doi.org/10.1016/j.appet.2009.11.015

White, M. (2007). Food access and obesity. Obesity Reviews, 8, 99-107. http://dx.doi.org/10.1111/ j.1467-789X.2007.00327.x

White, M., Williams, E., Raybould, S., Adamson, A., Bunting, J., \& Mathers, J. (2004). Do food deserts exist? A multi-level geographical analysis of the relationship between retail food access, socioeconomic position and dietary intake. Final report to the Food Standards Agency, UK School of Health Sciences, University of Newcastle upon Tyne, Newcastle.

Wrigley, N., Warm, D., \& Margetts, B. (2003).

Deprivation, diet, and food-retail access: Findings from the Leeds "food deserts" study. Environment and Planning A, 35(1), 151-188. http://dx.doi.org/10.1068/a35150

Wrigley, N., Warm, D., Margetts, B., \& Whelan, A. (2002). Assessing the impact of improved retail access on diet in a "food desert": A preliminary report. Urban Studies, 39(11), 2061-2082. http://dx.doi.org/10.1080/0042098022000011362

Zenk, S. N., Odoms-Young, A. M., Dallas, C., Hardy, E., Watkins, A., Hoskins-Wroten, J., \& Holland, L. (2011). You have to hunt for the fruits, the vegetables: Environmental barriers and adaptive strategies to acquire food in a low-income African American neighborhood. Health Education \& Behavior, 38(3), 282-292. http://dx.doi.org/10.1177/1090198110372877

Zenk, S. N., Schulz, A. J., Hollis-Neely, T., Campbell, R. T., Holmes, N., Watkins, G., Nwankwo, R., \& Odoms-Young, A. (2005). Fruit and vegetable intake in African Americans: Income and store characteristics. American Journal of Preventive Medicine, 29(1), 1-9. http://dx.doi.org/10.1016/j.amepre.2005.03.002

Zenk, S. N., Schulz, A. J., Israel, B. A., James, S. A., Bao, S. M., \& Wilson, M. L. (2005). Neighborhood racial composition, neighborhood poverty, and the spatial accessibility of supermarkets in metropolitan Detroit. American Journal of Public Health. 95(4), 660667. http://dx.doi.org/10.2105/AJPH.2004.042150 